УДК 321.1:321.021:32.019.52:311.2

DOI https://doi.org/10.32837/apfs.v0i27.936

\author{
В. М. Мельник \\ ORCID ID: https://orcid.org/0000-0001-5640-0351 \\ кандидат політичних наук, \\ асистент кафедри політологї \\ філософського факультету \\ Київського національного університету імені Тараса Шевченка, \\ головний редактор наукового журналу «Аннали юридичної історї̈»
}

\title{
ФЕНОМЕН «ТРАДИЦІЙНОГО» ЯК ЗАСІБ ЕКСПЛІКАЦІї ПОЛІТИЧНОЇ АНТРОПОЛОГІї
}

Контури проблеми. Як відомо, політична антропологія - це наукова дисципліна, що досліджує традиційні особливості політичної організації народів світу в історичній динаміці [18; 28]. В центрі iї уваги перебувають теоретичні концепти «традиційність» та «історична динаміка». Вивчення традиційних особливостей політичними антропологами проводиться виключно в двох середовищах, а саме соціокультурному та етносоціальному. Такий підхід, названий у науковій літературі антропологічним, передбачає нерозривність людської природи з етнічною свідомістю кожної окремої людини. Де-факто представники антропологічного спектру дисциплін запевняють, що етнічність та людське начало - це тотожні категорії [7; 19; 23]. Якщо в межах психологічної чи культурної антропології ще залишається простір для філософування та дискусій, то в теоретичному полі політантропології справа цілком вирішена: політичні традиції мають етнокультурне походження.

В українські науковій літературі вже опубліковано низку праць, присвячених становленню політичної антропології $[14 ; 16 ; 18 ; 20 ; 25 ; 28]$. Всі вони мають велике значення для політологічного дискурсу. Однак відкритим залишається головне питання про те, що вважати базовим маркером політико-антропологічних студій. На жаль, ми ще надто часто відчуваємо прагнення академічного кола вітчизняних політологів відносити предметну сферу політантропології до «компетенції» інших політичних дисциплін, зокрема етнополітології [17], етнодержавознавства, філософії політики [12].

Припинити наукову профанацію та перевести нарешті політичну антропологію в категорію «польової науки» [31, с. 3-21], що оперує вивченням політичних практик етнокультурної генези, вчене співтовариство зможе лише тоді, коли чітко задекларує предмет політичної антропології [28, с. 18].

Детермінація політичних традицій. Предметом політичної антропології є генетична передача та психологічна трансформація політичних традицій як основи політичної культури спільноти [24, с. 348-360]. Оскільки в історіографічному середовищі прийнято називати етнічні організми найбільш стійкими формами традиціоналістичного колективного світогляду, ми підтримуємо логічну думку антропологів В. Тишкова і М. Крадіна про «етноісторичний характер» політичної антропології загалом [31, с. 3-21].

Чим це пояснюється? По-перше, всі спільноти слід поділяти на «сталі» та «транзитивні» $[1 ; 2]$. По-друге, всі сталі спільноти спочатку групуються, а потім «консервуються» за ознакою компліментарності [23]. По-третє, науково виправданий принцип компліментарності зазвичай проявляється в етнічній самоорганізації спільнот [33].

«Транзитивні» спільноти, безумовно, володіють власними політичними традиціями, але їхня «транзитивність» полягає в безупинній трансформації цих традицій $[1 ; 2 ; 3 ; 8 ; 9]$. Крім того, серед соціокультурних антропологів прийнято розглядати «транзитивні» спільноти як перехідну форму етногенезу [23].

Спрощуючи запропоноване нами визначення предмета політичної антропології, спробуємо охарактеризувати його так: форми традиційного політичного устрою [27, с. 130-133].

Спробуємо виділити головні форми традиційного політичного устрою, які має вивчати сучасна політична антропологія. Для цього перш за все необхідно усвідомити, що політичний традиціоналізм того чи іншого суспільства безпосередньо залежить від контексту його історичного та етноісторичного розвитку. Особливо важливу роль відіграє етнопсихологія [13].

Під традиціоналізмом пропонуємо розуміти сукупність соціально-психологічних форм сприйняття звичаїв і традицій [4, с. 220-221]. Для традиціоналізму характерний поділ світогляду на «свій» та «чужий». Це робить традиціоналізм складовою частиною етніцизму як наукового підходу та етнічності як консервативного ступеня прояву ідентичності людини [17, с. 21].

Отже, поділяючи спільноти на доіндустріальні (тобто «примітивні» або «немодерні») та індустріальні (тобто сучасні), ми визначаємо різні за змістом, але об'єднані єдиним історичним процесом схеми локального устрою громадсько-політичного життя. Ми позбуваємось універсалізму, що, на 
думку Марка Леонардо, «шкодить сучасній політичній науці» [5, с. 250].

Говорячи про первісно-примітивні спільноти, як їх визначив англійський антрополог та етнолог Едуард Бернетт Тейлор (1832-1917 роки), маємо розуміти, що основою їхнього світогляду була релігія у всіх її початкових виявах. Безумовно, ці питання належать до сфери компетенції психоісторії та психологічної антропології, однак вони здійснюють прямий і безпосередній вплив на розвиток політичних традицій у прямій залежності від об'єктивних умов історичного процесу [1; 23].

Міфорелігійний політичний світогляд був характерним як для державних доіндустріальних (таких, що володіли суверенною державністю до початку промислових революцій), так і для недержавних, тобто первіснообщинних, спільнот. Спроба опису раннього громадсько-політичного життя людства 3 антропологічних позицій зроблена у класичних працях соціокультурних антропологів та етнографів Е. Тейлора («Первісна культура»), Дж. Макленнана («Теорія патріархату») та Дж. Леббока ( ППоходження цивілізації), виданих наприкінці XIX ст. На їхню антропологічну позицію (що часто супроводжувалась «біологізацією політичного») сильно вплинув «модний» тоді еволюціонізм Герберта Спенсера (1820-1903 роки), який, за влучною цитатою Івана Данилюка, «стверджував, що всі явища у світі - неорганічні, органічні й надорганічні - змінюються з часом у певному напрямі. Прості, спочатку гомогенні форми стають складнішими й гетерогенними. Їх частини дедалі більше диференціюються, але водночас вони краще інтегруються й організуються у вищерозміщені й підлеглі рівні. Еволюціонізм розвивається від нижчої до вищої та досконалішої організації, [13, с. 86].

Завдяки філософському генію Герберта Спенсера світова антропологічна думка остаточно стала на позиції прогресизму. Однак з'явилася цікава теоретична дилема. По-перше, прогрес $е$ категорією історичною (!). Відповідно, поза історичною еволюцією не варто шукати відповідей на актуальні соціальні виклики сьогодення. По-друге, антропологічний прогресизм розвився у два взаємовиключні напрями. 3 одного боку, з'явилися вчені-універсалісти (на кшталт самого Г. Спенсера), котрі стверджували єдність всесвітньо-історичного процесу та спільність соціально-культурних реакцій на зовнішні подразники і внутрішні трансформації. 3 іншого боку, від істориків-теоретиків відкололись так звані етніцисти (в історіографії коректно вживається також термін «націоналісти»), що розглядають всесвітньо-історичний процес як мозаїку унікальних етнічних і соціально-класових історій. Для «етніцистів» кожна етнічна спільність була продуктом і водночас продуцентом унікальної системи цінностей, до складу якої входять політичні тра- диції та правові звичаї. Саме у зв'язку з наведеним спрощеним узагальненням поглядів Герберта Спенсера (універсалістським) розвивалася спочатку політична антропологія Е. Еванса-Прічарда, Ж. Баландьє, А. Гольденвейзера та В. Маклеуда $[13$, c. $40-90,56]$.

Однак необхідно розуміти, що політична антропологія як вчення про закріплену історією традицію політичного світогляду (вираженого устроєм) певної спільноти не може повністю залежати від всеохоплюючої універсальної схеми, здатної «передбачити все» (як це проєктувалось еволюціоністськими розробками соціолога Г. Спенсера та етнографа Е. Тейлора).

Сьогодні кожен політичний антрополог має погодитись із спенсерівсько-тейлорівським баченням в одному. Політичний світогляд людського колективу безперервно еволюціонує, що слід аксіоматично визнати, посилаючись на характеристику еволюційного вчення, оформлену французьким соціокультурним антропологом Бруно Латуром [21, с. 20-32]. Для політичного антрополога з огляду на специфіку його діяльності важливо зрозуміти, чи не є безперервна еволюція політичного світогляду конкретної спільноти вираженою тільки назовні. Політична історія, як і історична політика, впевнено доводять, що еволюціонує лише форма вираження політичної активності. Зміст цієї активності, як і світоглядні передумови (інстинкти, традиції, ідентичність), залишається незмінним $[1 ; 2]$.

В низці попередніх публікацій ми вже писали про визначення принципу історизму, надане видатним німецьким філософом Мартіном Гайдеггером (1889-1976 роки). Для нього принцип історизму тотожний екзистенційному сприйняттю поняття “Dasein". Історичність знаходиться «тут і зараз", поміж нас. Ми думаємо історично, оскільки оцінюємо особисті дії/вчинки/думки саме в причинно-наслідковому зв'язку. Поза цією оцінкою не існує жодної людини. Навіть коли йдеться про особисте чи сімейне минуле/майбутнє. Все це керується принципом історизму, тотожним екзистенційному виміру «тут-буття» [9].

Хіба традиція не є буттям минулого в нашому сьогоденні [3]? Хіба відзначення різдвяно-новорічного циклу свят (в українському контексті) 3 давніми колядками та язичницькими щедрівками не є проявом гайдеггерівського "тут-буття» історизму в нашій свідомості? Хіба традиція не $€$ даниною нашої шани предкам? Питання дефініції традиції/традиціоналізму (обидва поняття не $е$ тотожними, але доповнюють одне одного) залишається дискутабельним. Однак, віддаючи належне традиціям психологічного єднання з духом предків у минулому, чому ми не повинні стверджувати наявність аналогічних традицій у політичній сфері? На наше глибоке переконання, політична 
антропологія покликана вирішити саме це складне питання. Досліджуючи політичні традиції, ми будемо вимушені заглибитись в усі тонкощі історичного процесу .

Слід критично ставитись до визначення Едуардом Тейлором традиціоналізму як «пережитку» (класичного в середовищі культурних антропологів), котрий не може відродитися за жодних обставин в еволюціонуючому «індустріалізованому» суспільстві. Тут, безумовно, треба визнати, що відродитись у своїй первинній формі синкретичної єдності з природою протягом процесу еволюції не може жодна ідейна або матеріальна форма (тим паче, людина як об'єкт антропологічного дискурсу). Однак будь-яка традиція завжди проходить певні етапи філософської та ідеологічної еволюції, заснованої на специфіці етноісторичних та етнопсихологічних процесів, що відбуваються у чіткому або розмитому географічному середовищі. Еволюція традиції не є однобокою, тобто не відкидає усе давнє або первісне, як вважали Е. Тейлор та Е. Еванс-Прічард. Наприклад, за Е. ЕвансомПрічардом, еволюція у політичній антропології має конкретну форму прояву: повна трансформація історичним процесом традиційного устрою, вивчати який можна лише на основі етнографічної методології, на основі збереження досвіду громадсько-політичної традиції в етнічній психології етносу або соціальній психології класу, що у майбутньому приводить до неодноразових дублювань цього досвіду в якісно новому форматі $[2 ; 13 ; 15]$.

Досвід останніх політико-антропологічних студій доводить, що найбільш виправданим (навіть зі спенсерівської еволюційної точки зору) методом оцінки та аналізу даних у політичній антропології є другий шлях, а саме дослідження факторів і ступенів збереження історико-політичного досвіду попередніх поколінь у генетичній пам'яті етносу [24; $25 ; 26]$.

Таким чином, визнаючи, що політична традиція проходить етапи еволюції від первіснообщинного ладу до сучасних демократичних практик, маємо зробити висновок, що протягом цієї хронологічно-психологічної еволюції у кожного етносу повторюється декілька характерних саме для нього традицій політичного процесу, що ідеологічно видозмінюються відповідно до особливостей тієї чи іншої історичної епохи $[4 ; 33]$.

Як політичні традиції вивчати? Виходячи 3 усього вищеозначеного, пропонуємо узагальнене бачення ролі поняття «політичні традиції» в теорії політичної антропології.

1) Політична антропологія $є$ вченням про ідейний та ідеологічний розвиток традиційних форм політичного устрою в історичному процеci, що безпосередньо стосуються сучасного стану політичної практики на рівні етносу та держави. Особливістю політичної антропології вважається її одночасна приналежність як до спектру по- літичних наук, так і до субдисциплін так званої соціокультурної антропології. Політичні антропологи вивчають традиційні для будь-якого етносу та соціальної групи форми політичної культури/ свідомості/активності шляхом порівняльного дослідження політико-правового устрою на прикладі як примітивних, так і розвинутих спільнот. Перехресне застосування методів різних гуманітарних наук дає змогу політичній антропології претендувати на виконання важливої функції моделювання майбутнього політичного процесу у певному соціально-етнічному середовищі. У політологічному контексті антропологом виступає такий дослідник, що фокусує власну увагу на традиційних формах політичного устрою конкретного суспільства [19]. В такому разі дослідник-політолог стає ще й політичним антропологом. Особливим предметом вивчення для нього є генетична передача та психологічна трансформація традиції як основи політичної культури етносу.

2) Політико-антропологічний науковий дискурс глибоко історичний. Це означає, що йому притаманний «принцип історизму» [11, с. 193-200]. Досі найкращим визначенням цього принципу слід вважати позицію Г.-В.-Ф. Гегеля про «логічність причинно-наслідкових зв'язків» . У сучасній історіографії антропоісторичних позицій у сприйнятті політичних явищ дотримується білоруський дослідник, фахівець 3 цивілізаційної теорії Я. Рієр [30]. Історичність явищ минулого сприймається антропологами як об'єктивність, оскільки вважається, що від минулого нам залишаються тільки «об'єктивні» образи суб'єктивного [29, с. 194-196]. Пам'ять зберігає найважливіше. Історія складається як архетипізована сукупність найголовніших фактів соціального буття. Ключовою позицією, що характеризує принцип історизму в політичній антропології, виступає специфічне антропологічне сприйняття людської свідомості. Кожна людина розглядається як носій політичних традицій, отриманих від предків [7]. Соціально-політична реальність, в якій опиняється кожне конкретне суспільство, 3 точки зору сучасної політичної антропології, так само $\epsilon$ «наслідком» певних «причин» [6]. Якщо ця реальність є несприятливою, то антропологи пропонують заглибитись у минуле задля дослідження головних помилок та їхнього недопущення в подальшому суспільно-політичному житті [28].

3) Зв'язок між політичною антропологією та історичною теорією полягає передусім у дослідницькому матеріалі, який історична наука постачає політичному антропологу $[5 ; 11 ; 15]$. Для того щоб аналізувати політичні традиції сьогодення та прогнозувати можливість їхньої соціальної трансформації у майбутньому, політичний антрополог має не лише добре знати сукупність історичних фактів, але й уміти заглиблюватись у менталь- 
ність попередніх поколінь, використовуючи спеціальний прийом (етіс-підхід - включений аналіз політичних традицій) [22, с. 518-529].

4) Традиціоналізм - ключовий елемент політико-антропологічного осмислення історії. Для політичної антропології традиціоналізм виступає сукупністю політичних традицій, постійне повторення яких протягом історичного процесу перетворюється на закономірність. Отже, можемо стверджувати, що «політико-антропологічний традиціоналізм» як суто науковий термін не має ознак традиціоналізму ідеологічного [23; 28].

5) Теорія політичної антропології базується на формулі «традиціоналізм - фундаменталізм консерватизм». У цьому контексті політична антропологія, фокусуючись на проблемі політичних традицій етнічних організмів, здатна виступати міцним філософським підгрунтям для націоналізму (як етнічного, так і громадянського), консерватизму та націонал-консерватизму. Це зумовлює ідеологічний антагонізм та категоричне несприйняття між традиціоналізмом, з одного боку (завжди етноцентричним), та антитрадиціоналізмом, 3 іншого ьоку (завжди глобалістичним), що змушує багатьох політичних антропологів говорити про предмет своїх досліджень як про «підгрунтя правих ідеологем» $[23 ; 24] .3$ огляду на особливості історичного, етноісторичного, етногеографічного та соціокультурного процесу, що витворив українську націю, створивши умови для вітчизняного національного державотворення, консервативна та націонал-консервативна ідеології, на наш суб'єктивний погляд, є найбільш прийнятними для соціально-психологічного та культурно-політичного відродження українства. Таким чином, політичні антропологи, кооперуючись у процесі своїх наукових досліджень, здатні розробити цілісну концепцію реорганізації політичної системи України, орієнтуючись на продукування традиційних для нашої території та нашого населення форм державного ладу. Головною проблемою політичної антропології у цьому контексті досі залишається розроблення критеріїв класифікації політичних традицій.

6) Розглядаючи українську політичну історію саме в аспекті політичної антропології, маємо підкреслити, що розроблення та вдосконалення вітчизняної політичної системи має відбуватись у тісній взаємодії з історичними традиціями нашого державотворення і традиціями «комплектування» владної вертикалі. Перш за все мають враховуватись історичний, етнографічний, етноісторичний, етнопсихологічний та соціально-психологічний досвід колективної свідомості. Дозволимо собі навіть припустити, що на основі політичної антропології існує можливість творення власної української політичної науки (з національним обличчям), у результаті чого будуть повернені закодовані на рівні етнічної психології традиції питомо української політичної системи та політичної культури. Тільки в разі звернення до політичних традицій минулого (сукупно осмислених як «політичний традиціоналізм»), українська політична наука, отже, політична система зможуть перебороти ту системну кризу, в якій вони опинилися на початку 2020 -х років.

\section{Jimepamypa}

1. Bourdieu P. Questions de Sociologie. Paris : Minuit, 1980. $268 \mathrm{p}$.

2. Bourdieu P. Les Structures Sociales de l'Economie. Paris : Seuil, 2000. 290 p.

3. Bourdieu P., Boltanski Luc. La Production de l'Ideologie Dominante. Paris : Demopolis, 2008. 158 p.

4. Cojanu D. Ethnicity as Social Fact and Symbolic Construction. Procedia - Social and Behavioral Sciences. 2014. Vol. 149. P. 217-221.

5. Krause S.R. History and the Human Soul in Montesquieu. History of Political Thought. 2003. Vol. 24. Issue 2. P. 235-261.

6. Lesaffer Randall. European Legal History. A Cultural and Political Perspective. Cambridge : Cambridge University Press, 2009. 556 p.

7. Баландье Ж. Політична антропологія / пер. з фр. О. Хоми. Київ : Альтерпрес, 2002. 252 с.

8. Бурдье П. Социология социального пространства. Санкт-Петербург : Алетейя, 2005. 288 с.

9. Бурдье П. Политическая онтология Мартина Хайдеггера. Москва : Праксис, 2003. 272 с.

10. Варзар I. Політична етнологія як наука: історіологія, теорія, методологія, праксеологія. Київ : Школяр, 1994. 224 с.

11. Васильев Ю. Понимание проблемы ценности в теории исторического процесса. Знание. Понимание. Уление. 2017. № 1. С. 193-200.

12. Воронов I. Людина і політика: у пошуках гуманістичної альтернативи : монографія. Київ : Генеза, 2004. 315 c.

13. Данилюк I. Етнічна психологія як галузь наукового знання: історико-теоретичний вимір. Київ, 2010. 432 с.

14. Денисенко В. Політика в контексті антропологічних вимірів. Вісник Національного технічного університету України «Київський політехнічний інститут». Політологія. Соціологія. Право. 2013. № 1. C. $34-39$.

15.ЖЖуков Е. Очерки методологии истории. Москва : Наука, 1987. 256 с.

16. Кирилюк Ф., Мельник В. Людина і громадянство в контексті парадигмального виміру політичної науки. Політологічний вісник. 2018. Вип. 80. С. 8-19.

17. Коршук Р. Етнополітологія. Київ : Алерта, 2011. $200 \mathrm{c}$.

18. Кравець А. Політична антропологія. Дніпро : Акцент, 2012. 178 c.

19.Крадин Н. Политическая антропология. Москва : Логос, 2010. 270 с.

20. Крисенко О. Політична антропологія: концептуальне поле та інституціоналізація досліджень. Вісник Харківського національного університету ілені В. Каразіна. Питання політологї. 2009. № 839. С. 6-12. 
21. Латур Б. Можем ли мы вернуться на Землю? Вокруг Света. 2011. № 12. С. 20-32.

22. Мельник В. Психологічні аспекти соціокультурної антропології. Вісник Вінницького наиіонального медичного університету. 2012. Т. 16. № 2. С. 518-529.

23. Мельник В. Нариси з теорії соціокультурної антропології. Вінниця : ТОВ «Вінницька міська друкарня», 2015. 552 c.

24. Мельник В. Теоретична конструкція політичної антропології. Гілея: науковий вісник. 2016. Вип. 113 (10). С. 348-360.

25. Мельник В. Три етапи становлення політичної антропології.ВісникЛьвівськогоуніверситету.Серія:Філософськополітологічні студї. 2019. Вип. 23. С. 190-195.

26. Мельник В. Дослідницькі групи та школи політичних антропологів: нова класифікація. Вісник Львівського університету. Серія: Філософсько-політологічні студї. 2019. Вип. 24. С. 171-183.

27. Мельник В. Політична антропологія: що та яким чином вона вивчає? Філософіл в сучаснолу науковолу та соціально-політичному дискурсах : матеріали доповідей та виступів Всеукраїнської науково-практичної конференції з міжнародною участю (19 листопада 2020 року). Вінниця : ВНМУ ім. М. Пирогова, 2020. С. 130-133.

28. Мельник В. У полоні інтерпретацій. Політична антропологія між Сходом і Заходом : монографія. Вінниця : Нова книга, 2020. 280 с.

29. Петрушенко О. Історія як літературна традиція. Аннали юридичної історї. 2018. Т. 2. № 1-2. С. 194-196.

30. Риер Я. Локальные цивилизации Средневековья: генезис и особенности. Могилев : МГУ им. А. Кулешова, 2016. $200 \mathrm{c}$.

31. Тишков В., Пивнева Е. Этнологические и антропологические исследования в Российской академической науке. Новая и новейшая история. 2010. № 2. С. 3-21.

32. Урсул А. Глобальные исследования и эволюционный подход. Москва : Издательство МГУ, 2013. 568 с.

33. Шажинбатын А. Этнос или этничность. Педагогика и просвещение. 2013. № 4. С. 368-375.

\section{Анотація}

Мельник В. М. Феномен «традиційного» як засіб експлікації політичної антропології. - Стаття.

У статті презентовані фахові роздуми про статус і наукове значення політичної антропології в сучасному світі. Основна увага автора зосереджена на поясненні предмета політичної антропології. Стверджується, що політична антропологія є вченням про ідейний та ідеологічний розвиток традиційних форм політичного устрою в історичному процесі, котрі безпосередньо стосуються сучасного стану політичної практики на рівні етносу та держави. Зауважується, що політичні традиції народжуються, функціонують і трансформуються виключно в межах процесів етносоціальної еволюції. Отже, всі політичні традиції детерміновані етнічно або культурно. Поза етнічною свідомістю політичні традиції довго не тримаються. Фактично значення політичної антропології полягає в репрезентації соціальних практик як «живих» систем, здатних до самовідтворення. Пояснюючи принципи детермінації політичних традицій, автор доводить, що історичність, притаманна всім формам людської свідомості, також повинна перебувати в об'єктиві наукових досліджень. Історичність - це кон- станта розвитку та поступу. Вона постулюється просторово-темпоральними рамками людського існування. Політика невід'ємна від історичності. Вона народжується поступом. Ось чому важливо застосовувати ретроспекцію та інтроспекцію для аналізу політичних традицій у політико-антропологічному дискурсі. Політичні традиції, осмислені на етнокультурному фундаменті, потребують окремого методу для дослідження. Деякі дослідники стверджують, що таким методом може стати етіс-підхід. Автор зазначає, що всі форми «включених студій» придатні для предмета політичної антропології. Політична антропологія передбачає постійне заглиблення науковця в коло його інтересів. Фактично справжній політантрополог є перманентним «співучасником» тих політичних дій, котрі він вивчає. На завершення статті автор надає власні зауваження щодо поняття «традиціоналізм», що має у політичній антропології значення, відмінне від сфери політичних ідеологій.

Ключові слова: політична антропологія, політичні традиції, політико-антропологічний традиціоналізм, предмет досліджень, історична динаміка, етнічність.

\section{Summary}

Melnyk V.M. The phenomenon of "traditional" as a means of explication of political anthropology. - Article.

The article presents professional reflections on the status and scientific significance of political anthropology in the modern world. The author focuses on explaining the subject of political anthropology. It is argued that political anthropology is the doctrine of ideological development of traditional forms of political system in the historical process, directly related to the current government and political practices at the level of ethnicity and state. It is noted that political traditions are born, function and transform exclusively within the processes of ethnical \& social evolution. Thus, all political traditions are determined ethnically or culturally. Outside the ethnic consciousness, political traditions do not last long. In essence, political anthropology's significance lies in the representation of social practices as "living" systems capable of self-reproduction. Explaining the principles of determination of political traditions, the author argues that historicity, inherent in all forms of human consciousness, must also be in the lens of scientific research. Historicity is a constant of development and progress. The spatial-temporal framework of human existence postulates it. Politics, in turn, is inseparable from historicity. That is why very important to use retrospection and introspection to analyze political traditions in political-anthropological discourse. Political traditions, understood as a product of the ethno cultural basis, need a separate method for research. Some researchers argue that it could be an "emic-approach". The author notes that all forms of "included studies" are suitable for the subject of political anthropology. Political anthropology involves the constant deepening of the scientist in the range of his interests. In fact, a true political anthropologist is a permanent "accomplice" of the political actions he studies. At the end of the article, the author provides his own remarks on the concept of "traditionalism", which in political anthropology has a different meaning from political ideologies.

Key words: political anthropology, political traditions, political-anthropological traditionalism, research subject, historical dynamics, ethnicity. 